\title{
ArcheoSciences
}

Revue d'archéométrie

\section{Modern and ancient gold jewellery attributed to the Etruscans: a science-based study}

Orfèvrerie moderne et ancienne attribuée aux Étrusques : une étude scientifique

Anna Rastrelli, Marcello Miccio, Lore G. Troalen, Marcos MartinónTorres, Maria Filomena Guerra, Salvatore Siano, Andrej Sumbera and Maria Luisa Vitobello

\section{OpenEdition}

\section{Journals}

\section{Electronic version}

URL: http://journals.openedition.org/archeosciences/2449

DOI: 10.4000/archeosciences.2449

ISBN: 978-2-7535-1598-7

ISSN: $2104-3728$

Publisher

Presses universitaires de Rennes

\section{Printed version}

Date of publication: 31 December 2009

Number of pages: $357-364$

ISBN: 978-2-7535-1181-1

ISSN: 1960-1360

\section{Electronic reference}

Anna Rastrelli, Marcello Miccio, Lore G. Troalen, Marcos Martinón-Torres, Maria Filomena Guerra,

Salvatore Siano, Andrej Sumbera and Maria Luisa Vitobello, « Modern and ancient gold jewellery attributed to the Etruscans: a science-based study », ArcheoSciences [Online], 33 | 2009, Online since 10 December 2012, connection on 01 May 2019. URL : http://journals.openedition.org/ archeosciences/2449; DOI : 10.4000/archeosciences.2449 


\title{
Modern and ancient gold jewellery attributed to the Etruscans: a science-based study
}

\section{Orfêvrerie moderne et ancienne attribuée aux Étrusques : une étude scientifique}

\author{
Anna Rastrelli*, Marcello Miccio*, Lore Troalen**, \\ Marcos Martinón-Torres***, Maria Filomena Guerra****, Salvatore Siano*****, \\ Andrej Sumbera****** and Maria Luisa VITObello*******
}

\begin{abstract}
A fibula with a lion and a pair of cluster earrings from the collection of the Florence National Museum of Archaeology, attributed to the Etruscans and said to originate from Populonia but suspected to be modern productions, were studied in the framework of the European project AUTHENTICO. They were compared to genuine objects from this same collection and from the collection of the National Museums Scotland. The study was carried out in situ in Florence with a stereomicroscope equipped with a digital camera, a handheld XRF spectrometer, and the portable LIPS prototype developed by AUTHENTICO. Some objects were studied with SEM and X-radiography. The aim of the study was to show that portable techniques of examination and analysis provide information on gold jewellery that allow the differentiation of modern and ancient productions.

Résumé : La fibule au lion et les boucles d'oreille à motifs floraux de la collection du musée national d'Archéologie de Florence, attribuées aux Étrusques, provenant de Populonia, mais suspectées d'être des productions modernes, ont été étudiées dans le cadre du projet européen AUTHENTICO et comparées à des objets originaux de cette même collection et de la collection des Musées Nationaux d'Écosse. L'étude a été réalisée in situ avec une loupe binoculaire équipée d'un appareil photo numérique, un analyseur de fluorescence X portable miniaturisé et le LIPS portable développé dans le cadre du projet AUTHENTICO. Certains objets ont été sélectionnés pour analyse au MEB et par radiographie. Le but de ce travail est de montrer que les informations obtenues grâce aux techniques portables d'examen et d'analyse permettent de différentier les productions modernes des anciennes.
\end{abstract}

Keywords: Etruscan, fakes, goldwork, XRF, LIPS, SEM, stereomicroscope.

Mots-clés : Étrusque, faux, orfevrerie, FX, LIPS, MEB, binoculaire.

\footnotetext{
* Soprintendenza Archeologica per la Toscana, Firenze-Centro di Restauro - Via della Pergola, 65, 50121 Floerence, Italy. (annarastrelli@yahoo.it)

** National Museums Scotland, Department of Conservation \& Analytical Research-242 West Granton Road, Edinburgh EH5 1JA. (l.troalen@nms. ac.uk)

*** UCL Institute of Archaeology-31-34 Gordon Square, London WC1H OPY, United Kingdom. (m.martinon-torres@ucl.ac.uk)

**** Laboratoire du Centre de Recherche et de Recherche et de Restauration des Musées de France, UMR171 CNRS - 14, quai François-Mitterrand, 75001 Paris, France (maria.guerra@culture.gouv.fr)

***** Istituto di Fisica Applicata, CNR - via Madonna del Piano (Ed C), 50019 Sesto Fiorentino (FI), Italy. (s.siano@ifac.cnr.it)

****** DIGART SME - Conservation \& Restoration - Vlnitá 56, 14700 Praha 4, Czech Republic. (a.sumbera@volny.cz)

******* EJTN GEIE, European Jewellery Technology Network - 124 rue du Commerce, Brussels, Belgium. (info@ejtn.org)
} 


\section{INTRODUCTION}

The high skill of the Etruscan goldsmiths is largely revealed by the incomparable quality, delicacy, and complexity of the filigree and granulation patterns of their jewellery, as well as by the thinness of the gold foils employed and the excellence of the joining techniques. Among the most representative objects of the $6^{\text {th }}$ century BC fine Etruscan gold work, the bauletto (basket) earrings can only be fully appreciated with a magnification lens.

Accurate observation at low and high magnification of Etruscan gold items produced around the $6^{\text {th }}$ century BC shows the following characteristics (Guerra, 2006; Guerra et al., 2007): plain and hollow granules may reach several millimetres but, in the case of dust granulation, their diameter may be as small as $120 \mu \mathrm{m}$; different wires - beaded, twisted, spooled, strip-twisted, etc. - may reach diameters of about $150 \mu \mathrm{m}$; and the gold foils used in the small pendant decorations are often about $100 \mu \mathrm{m}$ thick. The dimensions of the added decorative elements can be observed under the stereomicroscope in Figure 1 for one bauletto earring from the collection of the National Museums Scotland (NMS).

In Etruscan gold objects, joining is usually carried out by copper diffusion (Mello et al., 1983); the technique is described by Pliny, Theophilus and Cellini (Wolters, 1981). However, hard-soldering was also used for the application of large elements. The use of both techniques can be found in a single object, when, for example, decoration patterns are made with elements of different dimensions, such as the reels from Vulci (reference I.8 in Gaultier and Metzger, 2006), dated to the beginning of the $4^{\text {th }}$ century BC (Guerra et al., 2007).

In spite of the technical difficulties inherent to the reproduction of Etruscan work (Rudoe, 1991), partly owing to the lack of knowledge regarding Etruscan art, at least in the $19^{\text {th }}$ century, copies and imitations, as well as invented items of Etruscan inspiration, have been produced since the $18^{\text {th }}$ century for the antiquities market (Guerra, 2008a). The Pasinati cista and the Praeneste gold fibula, both attributed to Francesco Martinetti (Gordon, 1982; Williams, 1992), are known Etruscan fakes. The sarcophagus with the inscription of the gold fibula from Chiusi (Borrelli, 1992) purchased by the British Museum (Williams, 1992), the bronze chariot said to originate from Orvieto, and the colossal Etruscan warriors of Orvieto, purchased by the Metropolitan Museum of Art (Duchêne, 2006) are but three more examples of famous Etruscan fakes created by restorers who worked in the Campana workshop $\left(19^{\text {th }}\right.$ century, Rome). The Campana collection included nearly 15,000 objects according to Borrelli (1992), some genuine, other fantasist and unscrupulous fakes.
Many gold objects held in museum collections were repaired in the past. Others are either pastiches produced using heteroclite ancient parts, or fully modern inventions (Guerra, 2006; Guerra et al., 2007; Guerra, 2008b). This is the case of some of the objects presented in this paper: the fibula with a lion and a pair of cluster earrings from the collections of the Florence National Museum of Archaeology (FNMA). Purchased in 1911 from Maruzzi and assumed to originate from Populonia, they can be confidently revealed as modern fakes.

The aim of this work - carried out in the framework of the European project AUTHENTICO - is to provide analytical information on these objects, to compare their production technology and the composition of their alloys with genuine objects and pastiches from the FNMA, and to show how portable equipments can be used to provide criteria for the identification of modern jewellery. A small number of objects from the NMS were also analysed for comparison.

The study of the objects from the FNMA was carried out in the museum. They were examined under a SMZ1000 Nikon stereomicroscope equipped with a digital camera, and by X-radiography. The analysis of the alloys was carried out with a handheld X-ray fluorescence (XRF) spectrometer, Innov-X Systems Model Alpha 8000 LZX, with a silver tube, and operating at $40 \mathrm{kV}, 29 \mu \mathrm{A}$. The area of analysis was of about $6 \mathrm{~mm}^{2}$. Precision and accuracy were tested against a set of gold standard alloys (Table 1). The majority of the results provided are averages of 2-3 measurements and they have been normalised to $100 \mathrm{wt} \%$.

The objects studied at the NMS were examined using an Olympus stereomicroscope (Olympus SZX12 x 7-90) equipped with a digital camera (Olympus DP70), a CamScan Scanning Electron Microscope and a $300 \mathrm{kV}$ Pantak X-radiography system. They were also analysed by X-ray Fluorescence with an Oxford Instruments ED 2000 system, with a Rhodium target X-ray tube at $46 \mathrm{kV}$. Details on this equipment can be found in Troalen et al. (2009).

A few objects were selected for analysis with the portable low-cost laser induced plasma spectroscopy instrument (LIPS) developed in the scope of the European project AUTHENTICO, based on a compact Q-switched Nd:YAG laser (further details in Agresti et al., 2009). In this case, measurements were carried out with a spot of about $70 \mu \mathrm{m}$ diameter. Based on the different results obtained for the gold alloy standards of Table 1, the ablation could be limited to 100-200 $\mu \mathrm{m}$ laser pulses, which prevented major deposition of $\mathrm{Cu}$ and $\mathrm{Ag}$ oxides around the ablation hole, and allowed observing the saturation of the elemental depth profile towards the composition of the bulk. The total ablation 
depth was of about $60 \mu \mathrm{m}$. The calibration for quantitative elemental analyses was carried out with a set of gold alloy standards.

\section{Results}

The bow-shaped fibula with a lion and the pair of cluster earrings were purchased by the FNMA in 1911 as Etruscan jewellery from Populonia. The objects and their mounting, revealed by X-radiography, are shown in Figure 2. The fibula was produced in two parts: (1) the lion obtained by joining two embossed metal sheets decorated with granules; (2) the shank obtained by decorating a gold sheet with a line of five animals in granulation, outlined by two rows of granules. The $1 \mathrm{~mm}$ diameter spring is coiled one and a half times and soldered to the fibula under the lion. The cluster earrings consist of a horseshoe-shaped central element with a wide oval single piece clasp on the back. The central element is decorated with knurled and wavy wires, ropes, flowers with five petals and gold dust granulation, and it is adorned with hollow globules with a diameter ranging from 220 to $3000 \mu \mathrm{m}$.

The observation of the fibula under the stereomicroscope shows that the granules of 300-500 $\mu \mathrm{m}$ diameter forming the granulation patterns are joined by hard-soldering. Figure 3a reveals some solder left over on the metal sheet. In spite of being obtained by cutting small pieces of wires in an Etruscan tradition (Nestler and Formigli, 1994), as illustrated in Figure $3 \mathrm{~b}$, the granules are far too irregular to be considered as ancient work. Comparison of the granulation patterns from an ancient earring (Fig. 1) and the modern fibula (Figs. 3a and 3b) clearly shows this aspect. Formigli's (1985) assumption of a modern fabrication and our analytical results are confirmed by the observation of the spring, for which the use of a modern drawn wire, characterised by its mechanical seams (Oddy, 1977; Ogden, 1991; Swadling et al., 1991), is obvious (Fig. 3c). We also note that the section of the spring terminal is reduced by cutting with a chisel instead of being hammered, as expected for an ancient fabrication.

The cluster earrings show a quality of work very similar to the one of the lion fibula. Figure 4a shows details of the earring: the use of hard-soldering can be identified by observation only and the thick gold sheets with marks of file polishing on the borders that contrast with the delicacy of the lion's head and the flower of the genuine bauletto earring are shown in Figure 4b.

The filigree patterns are also of very dissimilar quality in modern and Etruscan productions (Ogden, 2004), such as
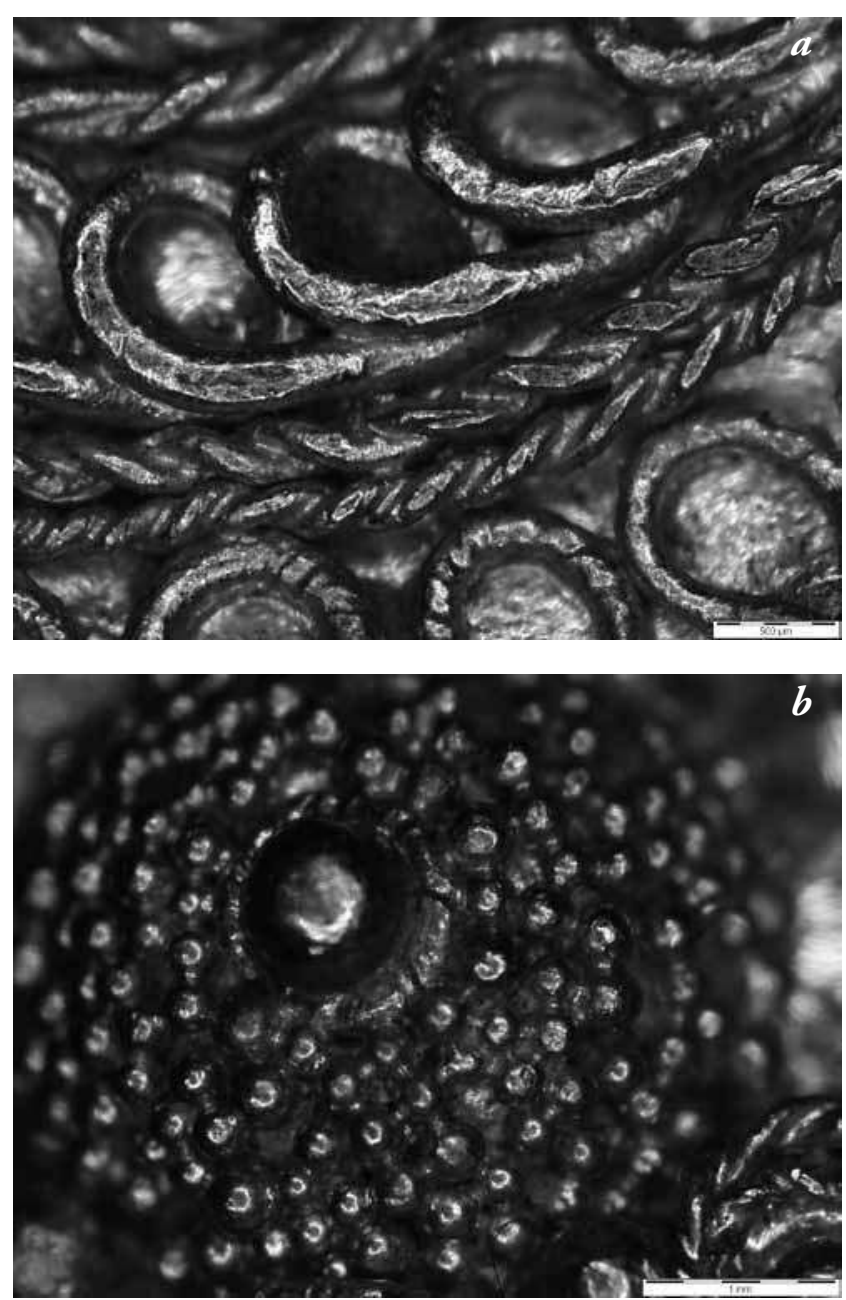

Figure 1: Details of a bauletto earring (reference K2004.40.1) from the NMS collection showing (a) filigree and (b) granulation patterns.

Figure 1 : Détails des motifs en (a) filigrane et (b) granulation de la boucle d'oreille à baule (référence K2004.40.1) de la collection du NMS.

in several objects belonging to the Campana collection held in the Louvre museum (Bagault et al., 2006). In order to illustrate these aspects, Figure 5 shows SEM-SEI images of earring A.1905.914.2 from the collections of the NMS. This earring consists of modern and ancient beads. The quality of the strip-twisted wires of the ancient granulated beads on Figure 5a, certainly joined by copper diffusion, contrasts with the quality of the beaded and block-twisted wires of the modern beads in Figure 5b, which were joined with thick hard-solder.

If we exclude some particular cases (such as the use of modern 18 carat gold alloys, Guerra et al., 2007), the composition of the modern and ancient alloys are in most cases 


\begin{tabular}{|c|c|c|c|c|c|}
\hline & & & $\mathrm{Au} \%$ & $\mathrm{Ag} \%$ & $\mathrm{Cu} \%$ \\
\hline \multirow{4}{*}{ Standards NMS } & \multirow{2}{*}{ Oxford rolled gold } & XRF & 79.4 & 10.6 & 10.0 \\
\hline & & Theoretical Value & 80.0 & 10.0 & 10.0 \\
\hline & \multirow{2}{*}{$\begin{array}{l}\text { Oxford GCS5 } \\
\text { gold }\end{array}$} & XRF & 80.0 & 17.1 & 2.9 \\
\hline & & Theoretical Value & 79.4 & 17.9 & 2.7 \\
\hline \multirow{8}{*}{$\begin{array}{l}\text { Standards } \\
\text { AUTHENTICO }\end{array}$} & \multirow{2}{*}{ Authentico A1 } & XRF & 92.1 & 6.7 & 1.2 \\
\hline & & Theoretical Value & 92.0 & 6.0 & 2.0 \\
\hline & \multirow{2}{*}{ Authentico A2 } & XRF & 71.3 & 25.1 & 3.6 \\
\hline & & Theoretical Value & 70.0 & 27.0 & 3.0 \\
\hline & \multirow{2}{*}{ Authentico E1 } & XRF & 47.0 & 53.0 & \\
\hline & & Theoretical Value & 50.0 & 50.0 & \\
\hline & \multirow{2}{*}{ Authentico E2 } & XRF & 51.9 & 47.7 & 0.5 \\
\hline & & Theoretical Value & 55.0 & 44.0 & 1.0 \\
\hline \multirow{10}{*}{$\begin{array}{l}\text { Standards } \\
\text { C2RMF }\end{array}$} & \multirow{2}{*}{ Lyon Allemand A } & XRF & 91.6 & 4.1 & 4.4 \\
\hline & & Theoretical Value & 92.0 & 4.0 & 4.0 \\
\hline & \multirow{2}{*}{$\begin{array}{l}\text { Lyon Allemand } \\
6917\end{array}$} & XRF & 74.2 & 18.9 & 7.0 \\
\hline & & Theoretical Value & 75.0 & 18.0 & 7.0 \\
\hline & \multirow{2}{*}{$\begin{array}{l}\text { Lyon Allemand } \\
6907\end{array}$} & XRF & 75.8 & 5.0 & 19.2 \\
\hline & & Theoretical Value & 75.2 & 5.7 & 19.1 \\
\hline & \multirow{2}{*}{$\begin{array}{l}\text { Lyon Allemand } \\
6905\end{array}$} & XRF & 74.4 & 6.8 & 18.8 \\
\hline & & Theoretical Value & 75.0 & 6.0 & 19.0 \\
\hline & \multirow{2}{*}{$\begin{array}{l}\text { Lyon Allemand } \\
6906\end{array}$} & XRF & 73.5 & 14.0 & 12.5 \\
\hline & & Theoretical Value & 75.0 & 12.5 & 12.5 \\
\hline
\end{tabular}

Table 1: Results obtained by stationary and handheld XRF for the gold alloy standards. Tableau 1: Compositions obtenues par fluorescence $X$ fixe et portable miniaturisée pour les standards d'or.
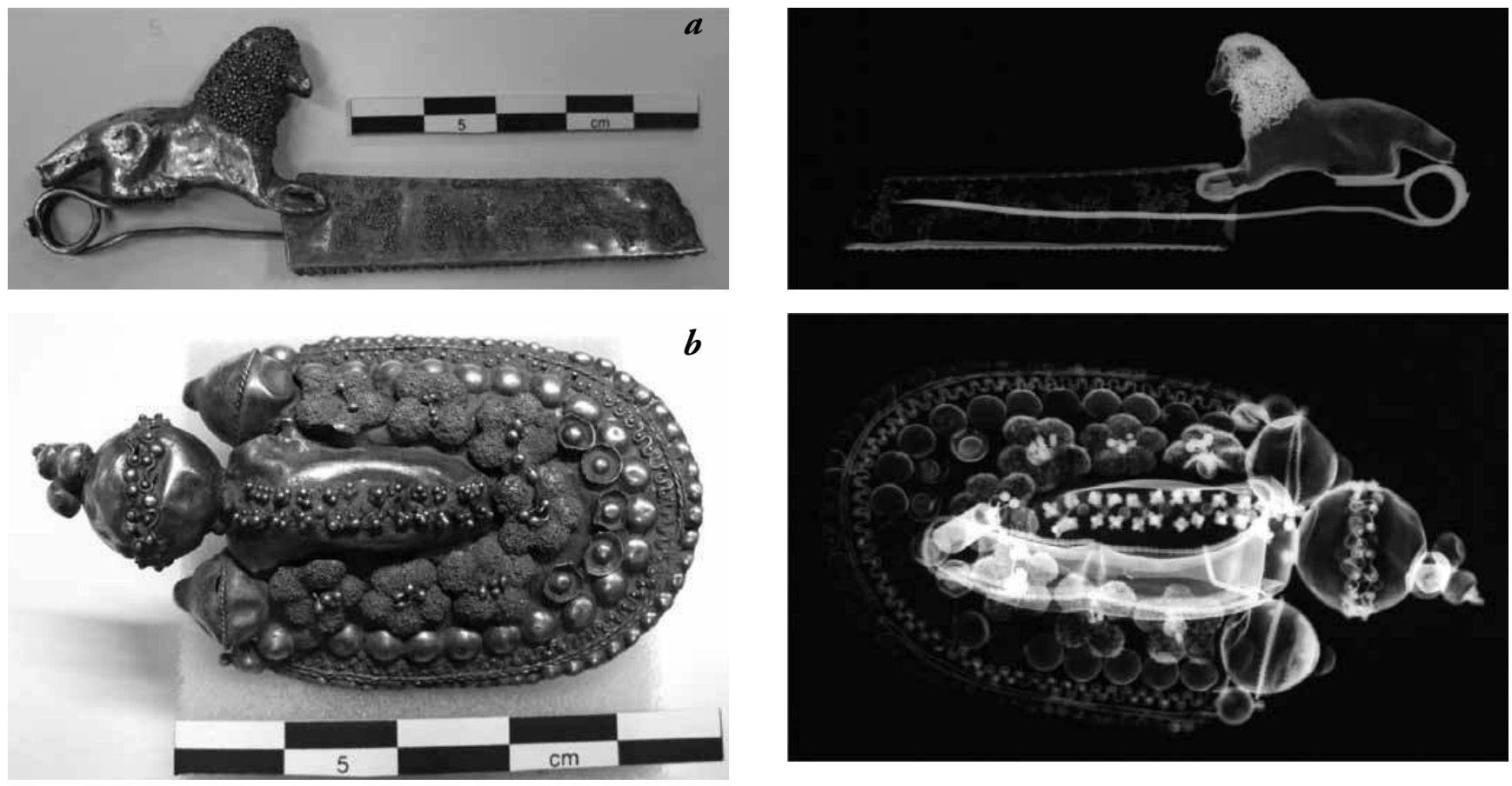

Figure 2: Photography and X-radiography of the FNMA (a) lion fibula (reference 85037: $14.05 \mathrm{~g} ; 9.4 \mathrm{~cm}$ long) and (b) one element of the pair of cluster earrings (reference 85036: $27.70 \mathrm{~g} ; 6.1 \mathrm{~cm}$ height and $3.5 \mathrm{~cm}$ large).

Figure 2: Photographie et radiographie à rayons $X$ de (a) la fibule au lion (référence 85037:14,05 g; 9,4 cm de longueur) et (b) d'une des boucles d'oreille à motifs floraux de la paire du FNMA (référence $85036: 27,70 \mathrm{~g} ; 6,1 \mathrm{~cm}$ de hauteur et $3.5 \mathrm{~cm}$ de largeur). 

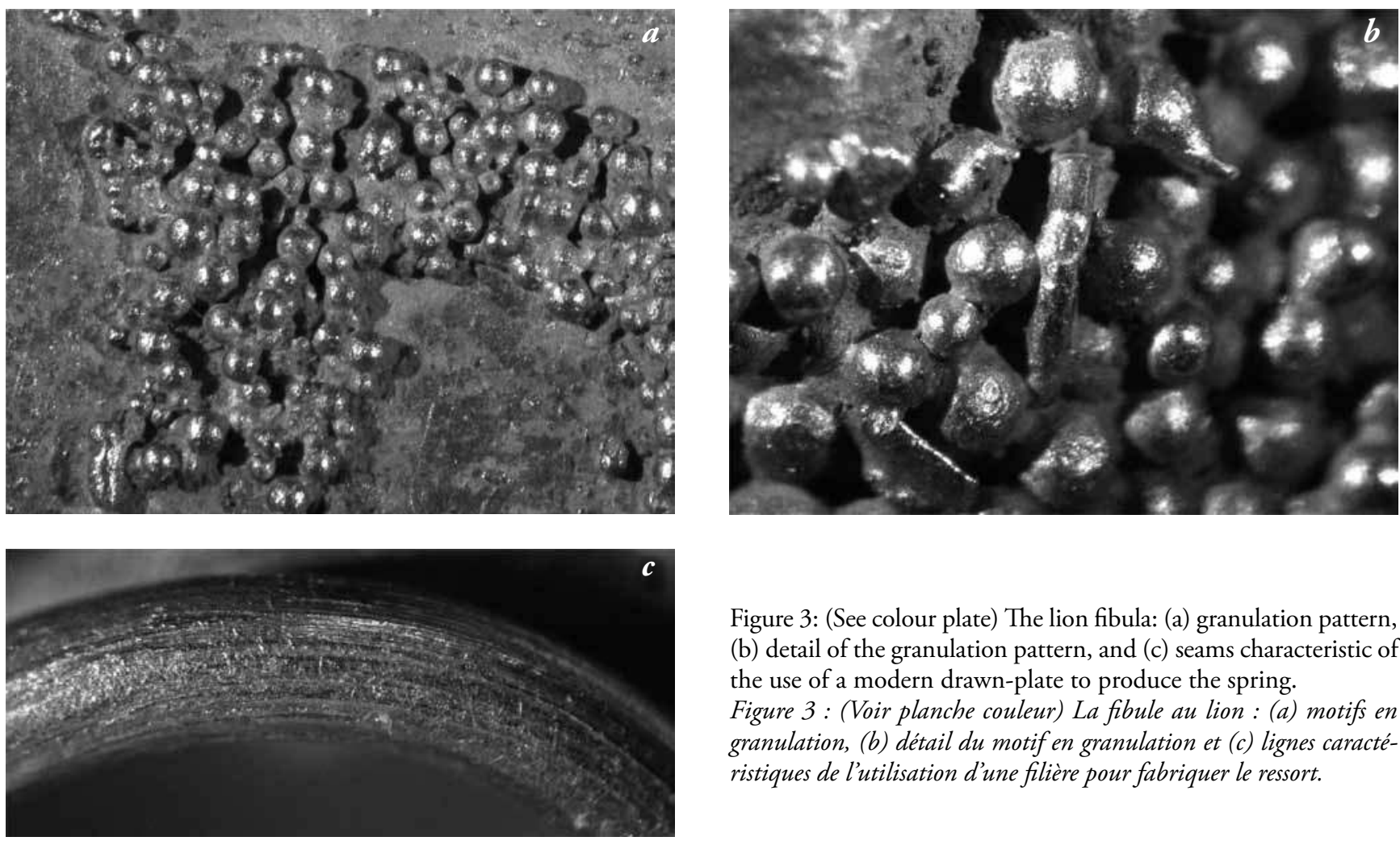

Figure 3: (See colour plate) The lion fibula: (a) granulation pattern, (b) detail of the granulation pattern, and (c) seams characteristic of the use of a modern drawn-plate to produce the spring.

Figure 3 : (Voir planche couleur) La fibule au lion: (a) motifs en granulation, (b) détail du motif en granulation et (c) lignes caractéristiques de l'utilisation d'une filière pour fabriquer le ressort.
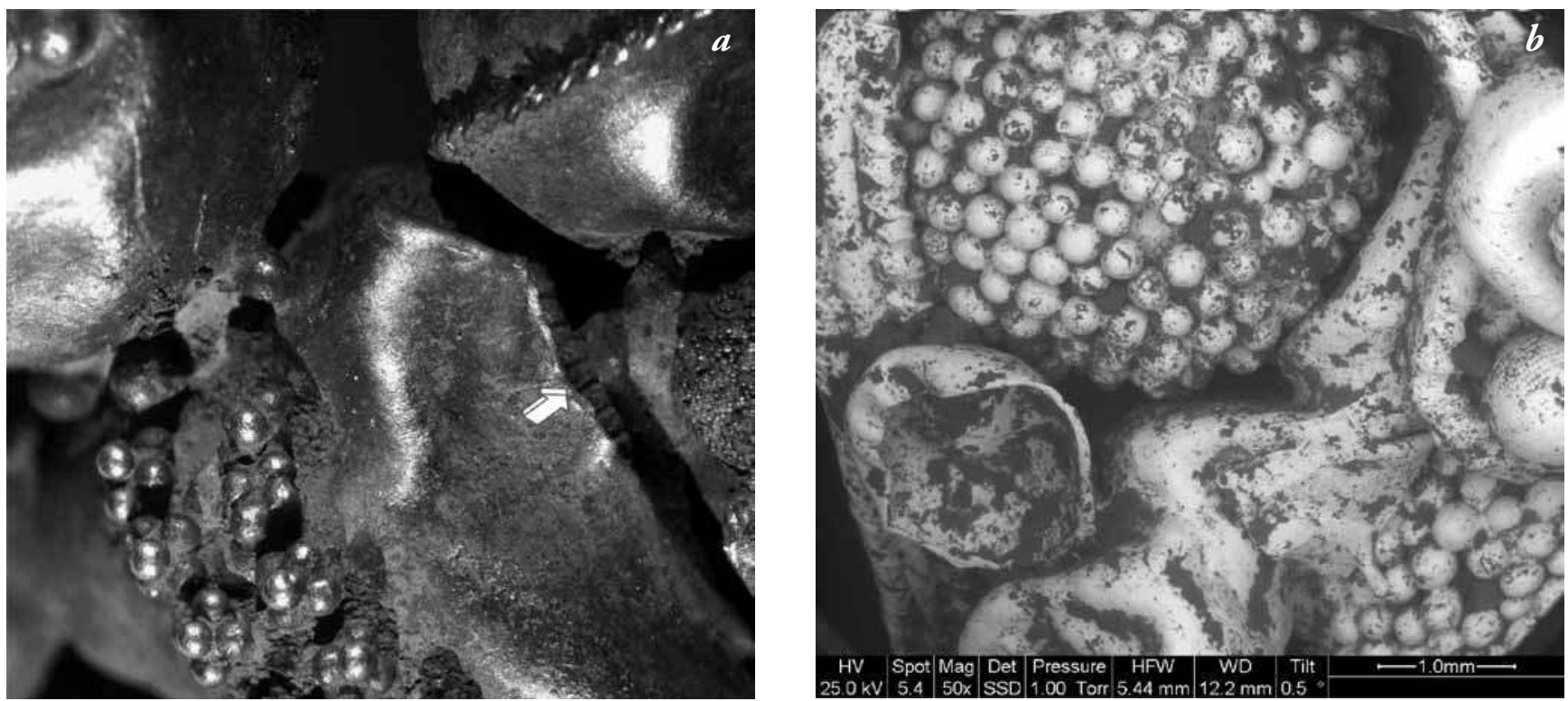

Figure 4: Details of the (a) modern cluster earring with indication of the file marks; (b) ancient bauletto earring reference 15718 FNMA (Currie's collection, 1836).

Figure 4: Détails de la boucle d'oreille à (a) motifs floraux modernes avec localisation des traces de lime et (b) baule étrusque référence 15718 FNMA (collection Currie 1836). 

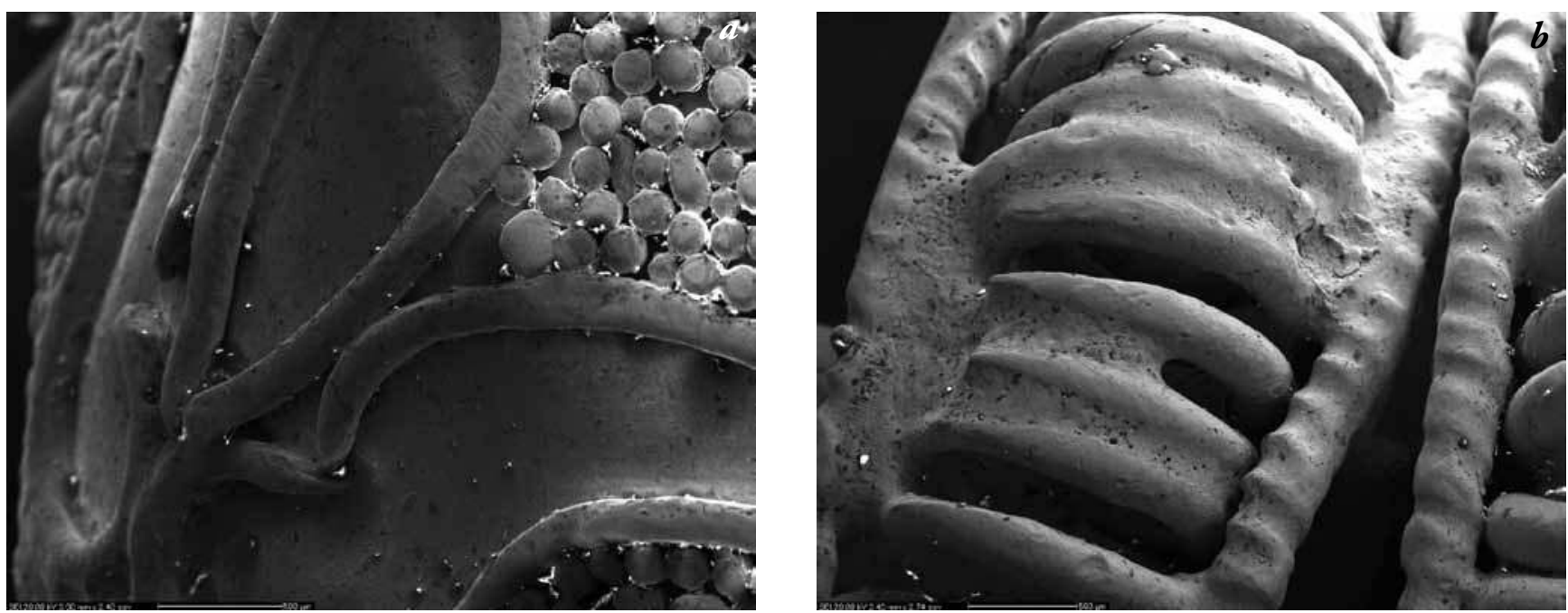

Figure 5: SEM-SEI micrographs of earring A.1905.914.2 from the NMS, showing the difference in quality between the (a) ancient and (b) modern gold work (scale: $500 \mu \mathrm{m}$ ).

Figure 5: Images MEB-SE de la boucle d'oreille A.1905.914.2 du NMS, montrant la différence de qualité du travail d'orfevrerie (a) ancien et (b) moderne (échelle: $500 \mu \mathrm{m}$ ).

barely different (Guerra, 2006; 2008b). In the present work, we analysed the lion fibula and the cluster earrings by portable XRF and LIPS. A few Etruscan bauletto earrings from the collections of FNAM and NMS, and a genuine pendant and a pastiche from NMS were also analysed for comparison. The results obtained are shown in Table 2.

Considering the fact that LIPS analysis is carried out on a small region of the object while XRF analysis is carried out on a large zone, which may include the region of interest (plate, granule, etc.) together with the solders, we can say that the results provided in Table 2 for the two techniques applied to the FNMA jewellery are in good agreement. The largest differences are observed for the bauletto earring 15718, which includes many decorative parts.

The results obtained for the lion fibula and the cluster earrings show the use of different alloys to produce their different parts. These alloys consistently have Ag values lower than $10 \%$, and $\mathrm{Cu}$ values lower than $3.5 \%$. Within the relative compositional variation, we can tentatively identify an alloy containing about $7-9 \% \mathrm{Ag}$ and $2-3 \% \mathrm{Cu}$, another containing about $5 \% \mathrm{Ag}$ and about $1 \% \mathrm{Cu}$, and a third one containing about $2 \% \mathrm{Ag}$ with variable contents of $\mathrm{Cu}$. We also note the use of different alloys for the production of the two elements of the pair of cluster earrings. The results obtained for the lion fibula and the cluster earrings are significantly different from the composition of the genuine objects analysed in the present work. They are also different from the results obtained for the modern parts of several published
Etruscan pastiches (Guerra, 2006; Guerra et al., 2007), such as cartouche finger-rings $(74-79 \% \mathrm{Au}, 15-21 \% \mathrm{Ag}$, and 3-6 $\mathrm{Cu} \%$, Guerra, 2006).

The high concentrations of silver and copper detected in the granulation applied to the lion's head are explained by the presence of leftover solder. Of potential interest is the notably high iron content detected on the earrings' surface (with one reading reaching a Fe concentration of 11\%): this is possibly due to a surface coating with iron oxides, which might be explained by the goldsmith's intention of giving to the modern productions the aspect of objects originating from archaeological excavations.

Earring A.1905.914.2, suspected to be a modern mounting of ancient and modern parts, shows a very homogeneous composition, with an average of $10.4 \% \mathrm{Ag}$ and $2.6 \%$ $\mathrm{Cu}$. This composition is distinct from the other published genuine objects, such as the Vulci reels, made with an alloy containing $97.5 \% \mathrm{Au}, 1.5 \% \mathrm{Ag}$, and $1 \% \mathrm{Cu}$, and the ancient parts of the hinged bracelets made with an alloy containing $94 \% \mathrm{Au}, 4 \% \mathrm{Ag}$ and $2 \% \mathrm{Cu}$, while the alloy of the modern parts contains $98 \% \mathrm{Au}, 1.3 \% \mathrm{Ag}$ and $0.7 \%$ $\mathrm{Cu}$ (Guerra et al., 2007). However, the granulated bead is without a doubt ancient. These results seem to indicate that the other beads could be partially ancient, but restored before being assembled in a modern mounting. The higher silver contents of this alloy are explained by the use of a silver-rich solder. 


\begin{tabular}{|c|c|c|c|c|}
\hline & $\mathrm{Cu} \%$ & $\mathrm{Ag} \%$ & $\mathrm{Au} \%$ & $\mathrm{Fe} \%$ \\
\hline \multicolumn{5}{|c|}{ FNAM XRF } \\
\hline \multicolumn{5}{|l|}{ Fibula 85037} \\
\hline lion's body & 0.4 & 2.7 & 96.3 & 0.6 \\
\hline granulation neck* & 3.4 & 17.4 & 77.0 & 2.2 \\
\hline spring & & & 100.0 & \\
\hline shank & 2.2 & 8.7 & 88.4 & 0.7 \\
\hline \multicolumn{5}{|c|}{ Cluster earring $85036 / 1$} \\
\hline back plate & 2.8 & 2.0 & 95.2 & $\leq 0.5$ \\
\hline three globules top & 3.5 & 9.7 & 85.6 & 1.2 \\
\hline side sphere top & 0.5 & 2.0 & 95.8 & 1.7 \\
\hline \multirow{2}{*}{ central sphere top $\begin{array}{l}1 \\
2\end{array}$} & 1.1 & 2.3 & 94.5 & 2.2 \\
\hline & 2.7 & 8.8 & 77.5 & 11.0 \\
\hline \multicolumn{5}{|c|}{ Cluster earring $85036 / 2$} \\
\hline front flower & 2.0 & 6.7 & 89.1 & 2.3 \\
\hline back hook & 1.1 & $\leq 0.2$ & 98.2 & 0.7 \\
\hline three globules top & 1.3 & 7.4 & 88.1 & 3.2 \\
\hline side sphere top & 1.0 & 4.9 & 93.4 & 0.7 \\
\hline central sphere top & 1.2 & 5.4 & 92.7 & 0.7 \\
\hline front flower & 1.9 & 5.7 & 88.8 & 3.6 \\
\hline \multicolumn{5}{|l|}{ Bauletto earring 15718} \\
\hline main barrel & 3.1 & 4.4 & 91.5 & 1.0 \\
\hline \multicolumn{5}{|l|}{ Bauletto earring 15751} \\
\hline main barrel & 2.7 & 17.8 & 78.5 & \\
\hline side plaque & 2.1 & 16.6 & 80.7 & \\
\hline \multicolumn{5}{|l|}{ Bauletto earring 7746} \\
\hline main barrel & 2.0 & 4.5 & 92.9 & \\
\hline side plaque & 2.9 & 4.5 & 92.2 & \\
\hline \multicolumn{5}{|c|}{ FNAM LIPS } \\
\hline \multicolumn{5}{|l|}{ Fibula 85037} \\
\hline lion's body & 0.2 & 1.4 & 98.4 & \\
\hline \multicolumn{5}{|c|}{ Cluster earring 85036/1 } \\
\hline back plate & 2.8 & 2.5 & 94.7 & \\
\hline \multicolumn{5}{|l|}{ Bauletto earring 15718} \\
\hline clasp & 2.0 & 3.5 & 94.5 & \\
\hline big granule & 1.9 & 2.9 & 95.2 & \\
\hline \multicolumn{4}{|c|}{ NMS XRF } & \\
\hline \multicolumn{5}{|c|}{ Bauletto earring A.1956.381 } \\
\hline Front plate & 1.9 & 1.9 & 96.2 & \\
\hline Lateral plate & 1.8 & 2.1 & 96.2 & \\
\hline \multicolumn{5}{|c|}{ Bauletto earring A.1956.381 A } \\
\hline \multirow[t]{2}{*}{ Front plate } & 2.3 & 1.9 & 95.8 & \\
\hline & 1.9 & 3.0 & 95.1 & \\
\hline Lateral plate & 1.7 & 1.8 & 96.5 & \\
\hline \multicolumn{5}{|l|}{ Earring A.1905.914.2 } \\
\hline Granulated bead & 2.7 & 11.3 & 86.0 & \\
\hline \multirow[t]{4}{*}{ Small bead } & 2.7 & 11.7 & 85.6 & \\
\hline & 2.5 & 10.7 & 86.8 & \\
\hline & 2.5 & 7.7 & 89.8 & \\
\hline & 2.7 & 10.7 & 86.6 & \\
\hline
\end{tabular}

* granules and solder together

Table 2: Compositions obtained for the different objects from FNMA and NMS collections analysed in this work by handheld XRF, stationary XRF, and portable LIPS

Tableau 2 : Compositions obtenues pour les différents objets appartenant aux collections du FNMA et du NMS, analysés pour ce travail par fluorescence $X$ avec système portable miniaturisée et fixe et par LIPS portable.

It is at this stage impossible to establish convincing criteria for the differentiation of modern and ancient productions by measuring only the elemental composition of the objects. Only the results published by Cesareo and Von Hase (1976) on the compositions of the reproductions of gold Etruscan objects made by Castellani in the $19^{\text {th }}$ century showed the use of different gold alloys, containing 2.5-6.6\% $\mathrm{Ag}$ and
0.6-2.2\% Cu. Some of these alloys are close to those obtained for the lion fibula and the cluster earrings. In any case, it has to be acknowledged that, given the variable compositions documented, it is not possible to discriminate modern from ancient gold items based on $\mathrm{Au} / \mathrm{Ag} / \mathrm{Cu}$ ratios only.

\section{ConClusion}

The analytical information obtained in the framework of the European project AUTHENTICO using portable equipment for the study of the lion fibula and the pair of cluster earrings from Populonia, attributed to the Etruscans and belonging to the collections of the FNMA, provided convincing evidence that they are fakes. Examination of these objects showed the use of thick gold sheets finished by file polishing, drawn wires, and big granules joined by hardsoldering. The delicacy of the Etruscan filigree and granulation patterns, the thinness of the gold foils, and the excellent joining techniques are not matched in the modern pieces.

The elemental analysis of Etruscan genuine gold items and pastiches from FNMA and NMS revealed the variety of the ancient and modern alloys, showing that composition alone does not provide sufficient criteria for distinguishing between ancient and modern productions. Etruscan genuine objects, pastiches with modern and ancient parts, and $19^{\text {th }}$ century reproductions of Etruscan objects published by different authors were also taken into account for this comparison.

Further comparison of the technical aspects of ancient and modern goldsmithing, as well as further analysis of the alloys used in the manufacture of modern and ancient gold items, should allow the establishment of an useful database for authentication assessment. In the present work, we note how both XRF with stationary and portable systems and LIPS can be successfully used in this type of study, even taking into account the error introduced by the analysis of non-flat surfaces and the different degrees of surface damage.

\section{References}

Agresti J., Mencaglia A.A. and Siano, S., 2009. Development and application of a portable LIPS system for characterising copper alloy artefacts. Analytical and Bioanalytical Chemistry 395(7): 1618-2642.

Bagault, D., Borel, T. and Guerra M.F., 2006. Les bracelets articulés de la collection Campana, in F. Gaultier, C. Metzger (eds.), Trésors antiques: bijoux de la collection Campana. Milan, 5 Continents; Paris, Musée du Louvre, 114-117. 
Borrelli, L.V., 1992. Faux, pastiches, imitations, in M. Pallotino (ed.), Les Étrusques et l'Europe. Paris, Réunion des musées nationaux, 432-439.

Cesareo, R. and Von Hase, F.W., 1976. Analisi di Ori Etruschi del VII sec. a.C. con uno strumento portatile che impiega la tecnica della fluorescenza X eccitata da radioisotope. Atti dei Convegni Lincei 11: 259-296.

Duchêne, H., 2006. La guerre du faux n'aura pas lieu. Dossiers d'Archéologie 312: 2-7.

Formigli, E., 1985. Techniche dell'oreficeria etrusca e romana: originali e falsificazioni. Firenz, Sansoni editore Nuova S.p.A.

Gaultier, F. and Metzger, C., 2006. La collection de bijoux: la composition, in F. Gaultier, C. Metzger (eds.), Trésors antiques: bijoux de la collection Campana. Milan, 5 Continents, Paris, Musée du Louvre, 192 p.

Gordon A.E., 1982. On la cosiddetta fibula Prenestina by Margherita Guarducci. The Classical Journal 78(1): 64-70.

Guerra, M.F., 2006. Etruscan gold jewellery pastiches of the Campana's collection revealed by scientific analysis, in $\mathrm{M}$. Cavallini, G.E. Gigante (eds.), De Re Metallica: dalla produzione antica alla copia moderna, Studia Archaeologica 150. Roma, L'Erma Di Bretschneider, 103-128.

Guerra, M.F., 2008a. Archaeometry and museums: Fifty years of curiosity and wonder. Archaeometry 50(6): 951-967.

Guerra, M.F., 2008b. Etruscan gold jewellery: genuine, restored or pastiche?, in S. Rovira Llorens, M. García-Heras, M. Gener Moret, I. Montero Ruiz (eds.), Actas del VII Congreso Ibérico de Arqueometría. Madrid, Quadro-CSIC, 479-489.

Guerra, M.F., Bagault, D., Borel, T., Di Mantova, A., Esquès, C. and Plé, E., 2007. Examen et analyse élémentaire de bijoux étrusques de la collection Campana, in F. Gaultier, C.
Metzger (eds.), Les bijoux de la collection Campana: de l'antique au pastiche. Paris, École du Louvre, 145-177.

Mello, E., Parrini, P. and Formigli, E., 1983. Etruscan Filigree: Welding Techniques of Two Gold Bracelets from Vetulonia. American Journal of Archaeology 87(4): 548-551.

Nestler, G. and Formigli, E., 1994. Granulazione Etrusca: Un'antica Tecnica Orafa. Siena: Nuova Immagine.

Oddy, A., 1977. The Production of Gold Wire in Antiquity. Gold Bulletin 10(3): 79-87.

Ogden, J., 1991. Classical gold wire: some aspects of its manufacture and use. Society of Jewellery Historians 5: 94-105.

Ogden, J., 2004. Revivers of the lost Art: Alessandro Castellani and the quest for classical precision, in S.W. Soros and S. Walker (eds.), Castellani and Italian Archaeological Jewelry. New Haven, London: Published for the Bard Graduate Center for Studies in the Decorative Arts, Design, and Culture, New York, by Yale University Press, 181-200.

Rudoe, J., 1991. Alessandro Castellani's letters to Henry Layard. Society of Jewellery Historians 5: 107-119.

Swaddling, J., Oddy, A. and Meeks, N., 1991. Etruscan and Other Early Gold Wire from Italy in Classical Gold Jewellery and the Classical Tradition. Society of Jewellery Historians 5: 7-21.

Troalen, L., Guerra, M.F., Tate, J. and Manley, B., 2009. Technological Study of Gold Jewellery from the 17th and 18th Dynasties in Egypt. ArcheoSciences 33.

Williams, D., 1992. The Brygos tomb reassembled and 19thcentury commerce in Capuan antiquities. American Journal of Archaeology 96(4): 617-636.

Wolters, J., 1981. The ancient craft of granulation. Gold Bulletin 14(3): 119-129. 